\title{
Montenegro and the NATO Partnership for Peace Program
}

\section{Mehmedin Tahirovic *}

\section{Abstract}

In contrast to the former republics of Yugoslavia that fought wars to reach their sovereignty, Montenegro achieved its independence democratically. This was a longer process, but it demonstrated that, even in the traditionally unstable Balkans, the most sensitive issues can be resolved peacefully, based on the concepts and principles of Western democracy. It is this specific feature of Montenegro that requires a special approach to finding adequate modalities to participate in the Partnership for Peace Program (PfP), taking into account the theory and practice of international relations.

It is particularly important to use thorough analysis to draw attention to Montenegro's specific circumstances, problems, needs, opportunities, and priorities as it prepares to enter the PfP. By following key mechanisms, the Euro-Atlantic Partnership and Council for Partnership and Individual Partner Relations may choose appropriate and adequate forms of cooperation and common activities with both Allies and Partners as well.

Based on research and the status of the police, economic, and security parameters described herein, efficient solutions related to common activities and Allies and Partners' direct assistance can be found so that Montenegro is able to actively participate and act within the Partnership for Peace Program.

Montenegro's geographic, demographic, economic, and other resources afford it the opportunity to contribute to the Partnership for Peace. Based on the facts at hand, viable forms of cooperation and engagement can be determined in order to engage the potential of Allies and Partners in common activities. Also worthy of note are the priorities required for the Partnership process to function smoothly, particularly those related to the resolution of common security problems, which presumes quality cooperation and meaningful contributions from all parties. The Partners' "Lessons Learned" constitute an especially good foundation, and can serve as guidelines that Montenegro can use to make appropriate decisions.

\section{Introduction}

The fall of the Berlin Wall in November 1989 marked the official end of the Cold War. Rapid changes in Central and Eastern Europe soon forced NATO to seek new and completely different avenues to address security challenges. Military capabilities appropriate to the times had been developed, giving rise to a constant conventional and nuclear arms race. Back then, the main focus of security was the nation-state - that is, its territory and political system; today, the citizen and his environment has become the focus of most dis-

* Mehmedin Tahirovic is an independent advisor for European and Euro-Atlantic integration to the Montenegro Police Directorate. This article was researched and written in January-February 2007 at the George C. Marshall European Center for Security Studies, Garmisch-Partenkirchen, Germany. 
cussions of security. Much contemporary research in the field of security is moving away from the realist approach toward a focus on theories of liberal institutional and critical approaches to security. ${ }^{1}$ This has resulted in a new theoretical model known as "cooperative security," involving the peaceful solution of conflicts between states not only by refraining from violence and threats, but also by utilizing various agreements aimed at finding practical solutions and taking precautionary measures. ${ }^{2}$ According to Professor Richard Cohen, the attempt to institutionalize the "Cooperative Security Concept" is important in order to correctly understand the development of the Partnership for Peace Program. ${ }^{3}$ Cohen proposes to institutionalize the Concept through security cooperation, which combines four elements: individual security; collective defense; collective security; and improving and spreading stability. The needs of the first and fourth elements influenced the development of the Partnership for Peace. Based on these theoretical assumptions, NATO became the only institution in the world possessing the power to institutionalize the "Cooperative Security Concept" by addressing relations within all four elements mentioned above.

In light of these theoretical principles, along with the social developments in Central and Eastern Europe, the NATO leadership and its specialists were faced with several questions: What measures are needed to take advantage of the opportunity to put European security on a new and positive footing after the confrontation of the Cold War? How may normal relations between Eastern and Western Europe be restored? What assistance should be rendered to Central and Eastern European countries to consolidate their recently gained independence and to accommodate their desire to participate regionally and globally, on an equal basis, as democratic countries on issues related to multinational security? ${ }^{4}$

These questions were answered by the leading countries of the Alliance at the London Summit in July 1990, after adopting the "London Declaration" when they extended a "hand of friendship" and offered new avenues of cooperation with all the countries of Central and Eastern Europe. By December 1991, the North Atlantic Cooperation Council was formed. This was a forum convened by NATO and its new partner countries at which issues related to common security interests were discussed. Initially the discussions within

1 Dragan Simić, The Science of Security: Contemporary Approach to Security (Belgrade: Official Gazette of the FRY and the Faculty of Political Science, 2002), 65-82.

2 The concept of "collective security" is derived from analyzed content and current definitions found in the following literature: Ashton Carter, William Perry, and John Streinbruner, A New Concept of Cooperative Security (Washington, D.C.: The Brookings Institution Press, 1993); Richard Cohen and Michael Mihalka, Cooperative Security: New Perspectives on the International Order (Garmisch-Partenkirchen: George C. Marshall, European Center for Security Studies, Publication No. 3, 2001), 3-4, 10, 35; I. William Zartman and Victor Kremenyuk, Cooperative Security: Reducing Third World Wars (Syracuse, NY: Syracuse University Press, 1995), 26; Gereth Evans, "Cooperative Security and Intra-State Conflict," Foreign Policy 96 (1994): 3-20; David Dewit, "Common, Comprehensive and Cooperative Security," The Pacific Review 7:1 (1994): 3 .

3 Cohen and Mihalka, Cooperative Security, 1-28; Dragan Simić, The Science of Security, 87101.

4 Radovan Vukadinovic, Post-Cold War Trends in International Relations (Zagreb: Faculty of Political Science, 2000). 
the North Atlantic Cooperation Council related to security issues remaining from the Cold War era. Everything was geared to a multilateral political dialogue, but there were no opportunities for special cooperation among all partner countries and NATO.

This changed with the establishment of the Partnership for Peace (PfP) Program - the main program for practical bilateral cooperation between NATO and individual partner countries. It represented a leap forward in the process of cooperation. A common statement by program founders and signatories to the Framework Documents at the Brussels summit on 19 January 1994 reads: "This Partnership for Peace has been established to jointly affirm that stability and security in the Euro-Atlantic space may be achieved only through cooperation and interaction. Guaranteeing and protecting basic freedoms and human rights, as well as protecting rights and peace through democracy, are the common values that lie at the core of the partnership., ${ }^{, 5}$

Events that marked the breakup of the former Republic of Yugoslavia provided a practical test of NATO's cooperation with its partners in the search for effective responses to present-day challenges and threats. While NATO changed to be able to address new challenges in the security environment, which itself had changed, the Partnership continued to evolve. In 1994 a Partnership Coordination Cell was established within the Supreme Headquarters Allied Powers Europe (SHAPE) in Mons, Belgium. The International Center for Coordination was established in 1995, also at the SHAPE headquarters. In the following year, the partner countries would participate in efforts led by NATO aimed at achieving a peace agreement in Bosnia and Herzegovina. In 1997 the Euro-Atlantic Partnership Council was established in Sintra, Portugal to replace the North Atlantic Cooperation Council, with the purpose of building an expanded and more effective partnership. The Partnership for Peace's operational role was increased that same year at the NATO Summit in Madrid. The following year, in 1998, the Euro-Atlantic Disaster Response Coordination Center was created.

Three Partner nations - the Czech Republic, Hungary, and Poland-joined NATO in 1999. Dialogue and cooperation are the primary components of the major security tasks incorporated in the Alliance's Strategic Concept. At the Washington Summit of the EuroAtlantic Partnership Council in 1999 it was agreed to continue to expand the Partnership for Peace and to strengthen its operational role. That same year, the Partner countries deployed forces that became part of the Kosovo force led by NATO. One day after the 11 September 2001 terrorist attacks in the United States, the Euro-Atlantic Partnership Council met and committed to joining all other countries in fighting terrorism. A broad review of the status and needs of the Partners and Allies at the Prague Summit of 2002 prompted the Euro-Atlantic Council and the PfP to draft a Partnership Action Plan to confront terrorism. In 2003, the Partners participated in the NATO-led International Security Assistance Force (ISAF). Seven Partner nations-Bulgaria, Estonia, Latvia, Lithuania, Romania, Slovakia, and Slovenia-joined NATO at the 2004 Istanbul Summit, where the decision was made to enhance the Partnership by adopting an Action Plan to build defense institutions. Two cycles of NATO enlargement have changed the balance among the Allies, which now number twenty-six countries, with twenty-three Partnership countries.

5 NATO Summit, Brussels, 1994. 
Special relationships with Russia and Ukraine were established after 1997 with the signing of the NATO-Russia Founding Act on interaction, cooperation, and security, and the Charter on the Special Partnership between NATO and Ukraine. Relations with Russia were strengthened with the establishment of the NATO-Russia Council in 2002, where the Allies and Russia met as equals. Steps were taken to deepen and broaden the NATOUkraine relationship with the adoption of the NATO-Ukraine Action Plan in November 2002, which aimed at supporting Ukraine's reform efforts required for full integration into the Euro-Atlantic security structures.

Considering that several Mediterranean countries of Southern Europe share borders with African countries and that European security is closely linked to that region's security, NATO undertook a new dialogue in 1995 with six southern Mediterranean nations: Egypt, Israel, Jordan, Mauritania, Morocco, and Tunisia. Algeria joined later, in $2000 .^{6}$

Due to Montenegro's particular relationship with Serbia in 1992, it unfortunately was not involved in the PfP enlargement process. After the breakup of the former Socialist Federal Republic of Yugoslavia, each constituent republic became an independent state in the process of security integration. Slovenia was the first to participate in the PfP from the time of its founding in 1994. Macedonia joined in 1995, with Croatia coming on board in 2000. Only after a referendum on independence on 21 May 2006, when Montenegro became an independent state, were efforts made to include it in the Partnership for Peace. In a letter to NATO Secretary-General Jaap de Hoop Scheffer on 30 August 2006, the government of Montenegro requested Montenegro to be accepted into the Partnership. After numerous doubts, Montenegro, along with Serbia and Bosnia and Herzegovina, was invited to join the Partnership at the NATO Summit in Riga on 29 November, while the Framework Agreement on accession to the PfP was signed at the NATO Center in Brussels on 14 December $2006 .^{7}$

Since Montenegro had restored its independence based on the principles of a modern democratic state, the country tried to make up for time lost over the previous fifteen years by quickly moving toward integration into the Euro-Atlantic security system. Mindful that various countries were showing interest in PfP membership and that such a preparation was a necessary part of the process of becoming a full-fledged member of NATO and then the EU, in June 2005 the Parliament of Montenegro passed the Declaration on European Integration, one part of which has to do with security integration. ${ }^{8}$ There is complete consensus among all political actors in Montenegro on the issue of integration; all are convinced that Montenegro will benefit greatly by implementing the prerequisites for accession to the Partnership for Peace Program, which include:

6 At the same time the NATO-Mediterranean Dialogue was developing, in November 1995, fifteen EU member states and twelve Mediterranean countries signed the Barcelona Declaration (known as the "Barcelona Process") to create a partnership on three levels: political and security, economy and finance, social and cultural. For more information, see www.nato.int/docu/home.htm.

7 The Framework Document was signed by President Filip Vujanovic of Montenegro. A presentation copy of the document was not provided due to a lack of time on the part of the Montenegrin authorities. It was agreed to deliver it at a later time.

8 Declaration of Accession to the European Union, Government of Montenegro, Doc. No. 36/3. 2005. 
- Regional security cooperation and improved relations with neighboring countries

- Democratization of society

- Administrative reform of the state sector

- Development and strengthening of state institutions

- Strengthening of the civilian sector and civilian control over the armed forces and other security structures

- Transparency and budget planning, monitoring, and oversight

- Assistance of experts in successfully restructuring and reforming the armed forces and security structures

- Specialization and training among security forces; participation in peacekeeping missions and in NATO forces

- Effectively fighting corruption and organized crime

- Creating a favorable policy and security climate for foreign investment.

Despite general agreement regarding these advantages, there are some differences of opinion among members of the Alliance and Partners in the PfP regarding mutual obligations in the fight on terrorism. ${ }^{9}$ Since Montenegro has made every effort to become a part of the Partnership for Peace Program, its potential capability to participate in, support, and carry out the Program's objectives is a major question that must be answered. Achieving the Alliance's standards both on a political and security level is a complex and dynamic process requiring coordinated actions and efforts by all governmental structures.

\section{Areas of Cooperation, Mechanisms and Functional Programs, Instruments and Plans for Implementing the Partnership for Peace}

It has been understood from the day of its founding at the 1994 Brussels Summit that at the core of the Partnership in particular, and of multinational cooperation more generally, are regular discussions and cooperative activities aimed at building openness and trust in the Euro-Atlantic region. On a bilateral level this requires developing a practical working relationship between some Partner countries and NATO that corresponds to their specific needs, situations, and capabilities. Certain areas, programs, instruments, and plans have been identified for the purpose of implementing the agreed-upon levels of cooperation and partnership. With time, these will be refined through special initiatives, declarations, and new working documents at NATO meetings and tailored to current requirements and to new security challenges.

For the purposes of this essay, only those content areas, programs, instruments, and action plans will be examined that are directly related to needs for the initial period of

9 A study was conducted recently by CEDEM (Center for Democracy and Human Rights). In their opinion, 36.9 percent of Montenegrin citizens were for NATO membership, while 31.4 percent were against it. At the same time, 76.5 percent support EU integration; only 5.6 percent are against it. See www.cedem.cg.yu. 
Montenegro's participation in the PfP, and especially those pertinent to eventual successful accession to NATO membership.

\section{Areas of Cooperation}

Areas of cooperation are mainly to be found in the Partnership Work Program. They are very diverse, and are not limited in scope. Each new program usually produces a new and expanded list, but the current set includes: $:^{10}$

- Air Force defense-related matters (ADF)

- Airspace management/control

- Consultations, command, and control, including communications and information systems, navigation and identification system, interoperability aspects, procedures and terminology (C3)

- Civil emergency planning (CEP)

- Crisis management (CRM)

- Democratic control of forces and defense structures (DCAF)

- Defense planning, budgeting, and resource management (DPF)

- Planning, organization, and management of national defense procurement programs, and international cooperation in the armaments field (DPM)

- Defense policy and strategy (DPS)

- Planning, organization, and management of national defense research and technology (DRT)

- Military geography (GEO)

- Foreign language training (LNG)

- Consumer logistics (LOG)

- Medical services (MED)

- Meteorological support for NATO partner armed forces

- Military infrastructure

- Political and military actions against the proliferation of nuclear, chemical, and biological weapons

- Concept, planning, and operational aspects of peace support efforts

- Operational, material, and management aspects of standardization

- Military exercises and related training activities

- Military education, professional development, and doctrine.

Cooperation in each of these areas pursues particular objectives and involves types of interaction (training sessions, conferences, working group sessions, visits, and other opportunities for dialogue) specific to the subjects and participating support organizations.

10 Partnership Work Program for 2000-01; available at www.nato.int/docu/handbook/2001. 
The contents of these areas are to be determined every two years and are the result of a general agreement among the Partner countries and the Allies. The Partners do not have to participate in each of these areas; they adopt only those in which they have an interest and which they are able to execute.

\section{Mechanisms}

The mechanisms of the Partnership for Peace represent a well-ordered system of relations between Partners and NATO aimed at accomplishing common objectives. This section will address the following PfP mechanisms: ${ }^{11}$

- Euro-Atlantic Partnership Council

- Partnership for Peace Trust Fund

- Euro-Atlantic Disaster Response Coordination Center.

Euro-Atlantic Partnership Council. The Euro-Atlantic Partnership Council (EAPC) offers a common political and security framework for multilateral and bilateral relations between NATO countries and members of the Partnership for Peace. It brings together NATO members and Partners in a single forum. All members of the Partnership for Peace are members of the Euro-Atlantic Partnership. At present, forty-nine countries participate in this multilateral forum, conducting regular dialogue and consultation, and making all significant decisions regarding the Partnership in the spheres of politics, economics, information, science, environment, defense, and military cooperation. ${ }^{12}$

The Euro-Atlantic Partnership Council has many variants (depending on the topic at hand) that allow for contacts between the Allies and Partners, as well as contacts within small but open working groups. The key to this type of activity is its flexibility. Most Partner countries have diplomatic missions at the NATO Headquarters in Brussels; this facilitates regular communication and affords the opportunity to consult when necessary. The Euro-Atlantic Partnership Council meets monthly at the ambassador level, annually at the ministerial level, and periodically holds summits. The EAPC Security Forum began meeting annually in 2005 to discuss significant security issues and ways that NATO could join with Partner countries to successfully address them. ${ }^{13}$

Partnership for Peace Trust Fund. The Partnership for Peace Trust Fund was established in 2000 as a mechanism to help Partner countries safely destroy their stockpiles of anti-personnel mines. After the successful elimination of many land mines, the fund's scope was expanded to include other demilitarization projects aimed at destroying munitions and infantry and light weapons. The use of Fund resources has increased in order to offer assistance to Partner countries in managing the consequences of defense reform through initiatives to retrain redundant military personnel, convert military equipment to other uses, or close down military bases. NATO members and Partner countries provide

11 Security Through Partnership (Brussels: NATO Public Diplomacy Division, 2005), 8, 28, 30; available at www.nato.int/docu/sec-partnership.

12 Bosnia and Herzegovina, Montenegro, and Serbia were invited to join the Partnership for Peace at the NATO Summit in Riga on 28-29 November 2006. Prior to that there were forty-six members in the EAPC.

13 For more about the Euro-Atlantic Partnership Council see www.nato.int/issues/eapc/index.html. 
funding on a voluntary basis, and may donate equipment or other materials. The NATO Maintenance and Supply Agency, located in Luxembourg, administers the projects and is responsible for implementing their technical and financial aspects. ${ }^{14}$

Euro-Atlantic Disaster Response Coordination Center. The Euro-Atlantic Disaster Response Coordination Center began operating in response to a Russian proposal in 1998 at the NATO Headquarters. The Center operates around the clock and represents a central clearinghouse for sharing information and coordinating NATO interaction with Partner countries in the event of natural catastrophes in the Euro-Atlantic area. The Center works closely with international emergency response and management agencies, including the United Nations Office for the Coordination of Humanitarian Affairs, the Organization for the Prohibition of Chemical Weapons, and other similar organizations. It arranges lengthy training exercises in civil emergency measures to develop responses to natural or manmade disasters, or to deal with the consequences of acts of terrorism involving chemical, biological, or radioactive substances. ${ }^{15}$ It was also agreed to form disaster response units made up of various national elements that the countries would make available on short notice when a disaster occurs. ${ }^{16}$

\section{Programs}

The PfP Program for partnership and cooperation should be considered as a dynamic and evolving process of developing relations between NATO and Partner countries. Considering that one of the main criteria of NATO is creating a "strong and operational Partnership," the entire process of building the Partnership for Peace has been characterized by constant efforts to improve it. The Partnership for Peace Framework Document contains the objectives that Partner countries are to pursue in their cooperation with NATO, as well as the Partner countries' and NATO's responsibilities and authority. ${ }^{17}$ During the preparation for the 1997 NATO Summit in Madrid, the idea of a more developed and robust Partnership emerged. This concept called for expanding and deepening its role. To implement this idea, in the spring of 1997 the foreign and defense ministers of the Allied countries proposed a number of measures to develop the PfP. These measures gave new impetus to the Partnership for Peace and significantly reinforced it in political, security, military, and institutional terms. ${ }^{18}$ Measures to develop a more operational partnership were ultimately adopted at the Washington Summit in 1999, in a report entitled "Toward a Partnership for the $21^{\text {st }}$ Century: The Enhanced and More Operational Partnership." 19

14 For additional information, visit www.nato.int/pfp/trust-fund.htm.

15 In 2002, Croatia organized exercises in conjunction with the Euro-Atlantic Disaster Response Coordination Center entitled: "Taming the Dragon-Dalmatia 2002." See Radovan Vukadinovic, Lidiya Cehulic, and Drago Lovric, NATO in International Relations (Zagreb: Faculty of Political Science, 2006), 161.

16 Additional information can be found at www.nato.int/eadrcc/home.htm.

17 Partnership for Peace Framework Document, agreed at the NATO Summit, Brussels, 1994, paragraphs $3,6-7$.

18 For more about this, see "MC Concept for PfP Enhancement" ( $2^{\text {nd }}$ draft), Members of the Military Cooperation Working Group with Cooperation Partners, Brussels, 1997.

19 "Partnership for Peace: An Enhanced and More Operational Partnership," NATO Summit, Washington, D.C., 1999. 
Today the PfP has become the main mechanism for implementing practical security ties between NATO and its Partners. The program's chief objective is increasing the level of stability, eliminating threats to peace, and building strong security relationships between individual Partner countries and NATO, as well as among the Partner countries themselves. To achieve this objective, each of the Partner countries can use bilateral cooperation to:

- Increase the number of troops available to participate in operations under the aegis of the United Nations and other organizations

- Conduct scientific research jointly with the Allies and other Partner countries

- Raise combat readiness to Western levels while meeting NATO standards

- Democratize its armed forces and increase civilian control of the military

- Develop a military doctrine and a national security system

- Utilize new NATO capacities.

The Partnership for Peace Program offers these opportunities on a voluntary, flexible, and transparent basis, respecting the principles of self-differentiation and accessibility.

The Security Through Science Program of the NATO Science Committee is aimed at using science to address challenges of security, stability, and solidarity among nations. This program supports collaboration on research topics such as the fight against terrorism and other security threats. The fight against terrorism has become the chief priority for the Allies and Partners, and NATO intends to render assistance to scientific research to develop more effective methods of detecting chemical, biological, radioactive, or nuclear weapons, and to develop measures that will offer protection from such attacks. Workshops and seminars are being organized to bring together scientists working on reducing threats to critical infrastructure (including energy, transportation, communications, and lifesupport systems); developing protection from eco- and cyberterrorism; improving border security; fighting human trafficking; and developing more effective means of detecting explosives. Threats to security and stability include environmental degradation (such as increased desertification, erosion of soil, or contamination of common waterways) and shortages of non-renewable resources, which may contribute to regional and border disputes. $^{20}$

The NATO Science Committee's Challenges of Modern Society program deals with issues related to protecting the environment and the public by calling upon national agencies to collaborate in conducting short-term and long-term studies in these fields. Activity is thus coordinated and information exchanged, which is then sent to the appropriate authorities in the region, ultimately exerting significant influence on measures to protect the environment. $^{21}$

NATO's Civilian Science Program is designed to afford scientists in the region easier access to information on recent scientific research. The idea is that, in addition to its con-

20 Security Through Partnership (Brussels: NATO Public Diplomacy Division, 2005), 33, 34; available at www.nato.int/docu/sec-partnership.

${ }^{21}$ Ibid. 
tribution to science, the program also has a role in preventing a monopoly on information and can be an important factor in the process of democratizing a society. In light of the fact that most Partner countries and their associates have little opportunity to take advantage of the benefits of the Information Age or realize the potential of the Internet, the NATO Civilian Science Program has provided many researchers and educational institutions with access to the Internet. ${ }^{22}$

\section{Instruments}

Partnership instruments can be used after receiving an invitation to become a Partner and signing the Partnership for Peace Framework Document, under which each Partner country assumes certain obligations. The next step for each Partner country is to develop and submit a Presentation Document, in which the Partner country, based on its ambitions and capabilities, identifies specific political, military, security, and other areas that the country wishes to develop together with NATO. ${ }^{23}$

A Partner country is accepted into the Partnership for Peace Program on the following conditions:

- Implementation of planned activities reflected in the Individual Partnership Program

- Participation in various PfP and NATO training activities

- Implementation of activities in the plans for bilateral cooperation with other Partner countries

- Preparation and implementation of PfP operations under NATO supervision

- Participation of Partner countries in the fight against terrorism.

Activities to be implemented within the framework of Partnership instruments are planned and approved according to the appropriate political and military activity frameworks. The major frameworks in the Program are:

- Partnership for Peace Framework Document

- Political and Military Framework for PfP operations under NATO's leadership role

- Partners' Action Plan for participation in the fight against terrorism

- Combined Joint Task Force Concept.

It should be emphasized that for Partner countries the achievement of capabilities, implementation of PfP operations under NATO supervision, and participation in the fight against terrorism are major imperatives for participation in the PfP.

The Partner country carries out these activities through the main Partnership Instruments within the framework of the respective military-political rules. All important decisions related to a Partner country's activities are made within the Euro-Atlantic Partnership Council, while the instruments are prepared by Partner and NATO working groups. The PfP Working Groups offer opportunities for coordinating Partners' capabilities via the

22 Ibid., 35.

23 NATO Handbook (Brussels: NATO Public Diplomacy Division, 2006); available at www.nato.int/ docu/handbook/2006. 
Partnership Instruments and for improving the Instruments. The PfP Working Groups include:

- Political-Military Steering Committee on the Partnership for Peace

- Defense Working Group for Military Cooperation

- Cell for Partnership Coordination

- PfP divisions at NATO headquarters.

Activity instruments in the Partnership for Peace facilitate cooperation between Partners and NATO and afford Partner countries the opportunity to prepare their forces for future membership. This section will address the following PfP instruments:

- Partnership Work Program (PWP)

- Individual Partnership Program (IPP)

- Planning and Review Process (PARP).

Partnership Work Programs (PWP) and Individual Partnership Programs (IPP) are PfP instruments that, through the principle of self-differentiation, allow each Partner country to select areas in which they will carry out certain activities together with NATO. The Partnership Work Program offers a "menu" of activities that the Partner country can perform with NATO. ${ }^{24}$ The Individual Partnership Program is a bilateral agreement between Partner countries and NATO that governs the joint accomplishment of selected activities from the Work Program, as mentioned earlier in the section on Areas of Cooperation.

Under the Partnership Work Program's Individual Programs, each Partner nation works to achieve interoperability in their selected area of focus. The NATO Glossary of Terms and Definitions defines interoperability as the "ability of the NATO forces, and when required, forces of Partner countries and other non-NATO countries, to utilize common equipment and training and successfully work together to perform assigned missions and tasks." ${ }^{25}$ From this definition, one can conclude that interoperability implies a set of capabilities of Allied and Partner forces that provides the efficiency required to carry out joint activities. If we recall that the Partnership for Peace represents a bilateral agreement between NATO and the Partner country, it follows that interoperability within the Partnership provides the Partner country the ability to join NATO in executing joint activities. Interoperability within the Partnership for Peace is first reflected in the ability of Partner country forces to carry out PfP operations under NATO supervision and participate in the fight against terrorism. Interoperability is achieved in operational, material, and administrative areas. For the Individual Partnership Program, key areas of focus for achieving interoperability include military procedures and actions, military equipment, consultation systems, command and control, logistics, and terminology. The primary means of achiev-

24 Vukadinovic, et al., NATO in International Relations, 161.

25 NATO Glossary of Terms and Definitions (Brussels: NATO, document AAP-6, updated April 2007), 2-I-7; available at www.nato.int/docu/stanag/aap006/aap6.htm. 
ing interoperability is standardization, which implies common development and implementation of the NATO Standardization Documents.

Under the new NATO standardization programs it has been decided that to achieve interoperability it is necessary to implement operational and administrative standardization at the level of common interests and standardization of materials both in terms of compatibility and replacement when it comes to multinational forces' munitions, supply, and repair and maintenance. This permits participation in the standardization process for new NATO members, Partner countries, and other non-NATO countries whose military equipment has not yet achieved a common level in the material standardization process. A Partner country achieves interoperability by actively participating in the NATO standardization process and by adopting and implementing NATO Standardization Documents through Partnership Instruments, but first and foremost through the Individual Partnership Program. It is also important to stress that in the process of achieving interoperability by implementing planned activities from the IPP, each Partner is geared to specific regulatory frameworks that define important areas of force interoperability, primarily those specified in the Defense Capabilities Initiative ${ }^{26}$ and the Prague Capabilities Commitment. ${ }^{27}$

The Planning and Review Process (PARP) is an instrument that offers the opportunity to clearly identify and assess forces and capabilities that might be used in the process of multinational training exercises and operations with NATO forces. ${ }^{28}$ The Planning and Review Process builds on NATO's significant experience in defense planning. During preparation for the Madrid Summit in 1997, NATO defense and foreign ministers adopted several recommendations. It was decided to develop political courses for planning the process for each PARP cycle, with the consent of the defense ministers of the participating countries. These courses perform the same function as the NATO ministerial defense planning structure. In addition, it was decided to extend the PARP cycle from two to six years.

Not all Partner countries are obliged to participate in the PARP; rather, participation is purely elective. The process helps the Partners to establish robust and strong armed forces and to implement major efforts in defense reform. ${ }^{29}$ This is a cyclical process involving bilateral and multilateral factors. The bilateral aspect is reflected in the fact that each Partner wishing to participate in the PARP assumes responsibility for a certain cycle and provides NATO with information on its defense policy, its progress in advancing democratic control of its armed forces, its national policies on cooperation within the PfP, relevant financial and economic plans, and many other issues. ${ }^{30}$ A planning and review process is developed for each Partner nation based on the information the Partner provides in its response to the "Survey on Overall PfP Interoperability." Especially important is preparation of the Partnership Goals, which indicate the measures to be taken by each Partner in order to achieve interoperability within the PfP (in essence, by implementing the Partnership Goals, the Partner countries achieve interoperability within the PfP and prepare their 
forces for future NATO membership). ${ }^{31}$ The Partner nation and NATO then jointly approve the Planning and Review Assessment and Partnership Goals. Finally, representatives of NATO and of all countries participating in the PARP approve a Consolidated Report, which briefly describes each accepted assessment and the forces made available by the Partner countries.

\section{Action Plans}

The Membership Action Plan (MAP) is based on the need for NATO enlargement in former communist countries based on the 1999 Washington agreement. ${ }^{32}$ The Membership Action Plan enables the integration of all the activities of candidates for NATO membership prior to entering the process, and permits NATO and the candidate nations to manage this process. When the Czech Republic, Hungary, and Poland were accepted into NATO membership, it was realized how difficult and complex the process was, and the decision was made to simplify the process by establishing clearly defined areas of activity. The Membership Action Plan provides a catalog that describes the desired profile and characteristics of a NATO aspirant in five spheres of activity: political and social, defense and military, financial, security, and law. For all categories the candidate country prepares an Annual National Program (ANP), which it submits to NATO. This process is a special procedure wherein the ANP submitted in the previous year is substantiated before representatives of all twenty-six NATO members, each of which makes comments and suggestions and asks questions. The document's heading specifies steps to be taken to achieve interoperability in the sections designated by the deputy ministers of defense or foreign affairs who lead their nations' military agencies. The MAP is implemented in four annual cycles. After each annual cycle, the foreign and defense ministers present the results of the reform programs and future activities to the NATO Council, which then assesses individual nations' success in preparing for membership. Going through four cycles does not guarantee that a candidate country will be invited to become a NATO member.

Individual Partnership Action Plans (IPAP) were adopted at the Prague Summit in November 2002 and apply to Partners that possess the political will and ability to deepen their relationship with the NATO Alliance. Plans are developed for two-year periods; they must clearly define the Partners' objectives and priorities, and must specify mechanisms that directly support those priorities. The objectives identified relate to political and military issues, security, public information, science and environmental protection, civil and emergency planning, administrative issues, and resources. ${ }^{33}$

The Partnership Action Plan Against Terrorism began functioning after the terrorist attacks on the U.S. in September 2001. Those events were an impetus to the further development of the Partnership for Peace. The Partners and Allies within the Euro-Atlantic Partnership Council made a common decision for the Partners to take part in joint actions against terrorism. Later, the Action Plan Against Terrorism was adopted at the 2002 NATO Summit in Prague. This plan provides the framework for cooperation and sharing

31 Vukadinovic, et al., NATO in International Relations, 155.

32 "Membership Action Plan," NATO Summit, Washington, D.C., 1999.

33 Additional information is available at www.nato.int/issues/eapc/index.html and www.nato.int/ issues/pfp/index.html. 
experience in this field via political consultation and practical measures. It promotes better sharing of intelligence information and collaboration in such fields as border security, antiterrorism training, and developing better capabilities to protect or recover from terrorist attacks. $^{34}$

The Partnership Action Plan on Defense Institution Building was established at the NATO Summit in Istanbul in June 2004. The plan's objective is to strengthen Partners' efforts to initiate and implement the reform and restructuring of their defense institutions in accordance with domestic needs and international commitments. The Action Plan's objectives include: effective and transparent agreements on democratic control of defense activities; public participation in developing defense and security policy; effective and transparent legal and judiciary oversight of the defense sector; better assessment of security risks and national defense requirements consistent with developing and maintaining capacity; willingness to manage defense ministries and other agencies with joint force structures; harmonization with international rules and experience in the defense sector, including export control; effective and transparent financial procedures; defense planning and resource allocation procedures; effective management of defense spending and of the socioeconomic consequences of defense restructuring; effective and transparent structures and activities of defense sector employees; effective international cooperation and neighborly relations on defense and security issues. One of the best examples of how the points in this plan can be applied can be found in Ukraine's reform of its defense sector. ${ }^{35}$

A key element of the plan is training and education in the context of defense transformation. That was the objective of establishing eleven Training Centers and three NATO schools. The training centers are distributed so as to provide diverse and comprehensive forms of training and professional development to both Partner states and NATO members. The training centers are:

- Austrian Training Center for Peacekeeping Operations

- Finnish Defense Forces International Center

- Multinational Peace Support Operations Center, in Greece

- PfP Regional Center for Defense Resources Management, Romania

- National Defense Academy in Slovakia

- PfP Language Training Center, Slovenia

- Swedish Armed Forces International Center

- Geneva Center for Security Policy

- PfP Training Center, Turkey

- Yavorov PfP Training Center

- U.S. Army Postgraduate School.

34 Security Through Partnership, 15.

35 Ibid., 24-26. Additional information available at www.nato.int/docu/nato_after_istanbul. 
The three NATO schools established under the rubric of this action plan are the NATO Defense College in Rome, the NATO Communications and Information Systems School in Latina, Italy, and the NATO School in Oberammergau, Germany. ${ }^{36}$

All of these fields and activities, mechanisms and action programs, instruments, and implementation plans have been instituted to achieve a high level of cooperation to more effectively realize treaty obligations and commitments under the Partnership for Peace, so that Partners may be more rapidly engaged in the Euro-Atlantic security system. They are evolutionary and dynamic, and are geared to regional and world security challenges and threats.

\section{Specific Circumstances of Montenegro and Challenges it Faces in Joining the Partnership for Peace}

Montenegro entered a new chapter in its history after 21 May 2006, when it became independent by referendum. Although the period from 1992 (when the Federal Republic of Yugoslavia was formed with Serbia) to 2003, which saw the declaration of the State Union of SCG, can be considered lost time for Montenegro in terms of the processes of European and Euro-Atlantic integration, this is nonetheless considered an important fact relating to its relationship with other republics of the SFRY. Montenegro is the smallest of the former Yugoslav republics, with a population of 620,145 according to the 2003 census. Out of these, 70 percent belong to one form or another of Orthodox Christianity. The largest ethnic group of the population is Montenegrins, at 43 percent, then Serbs at 32 percent, followed by Bosnians, Albanians, Croatians and other smaller ethnic groups.

Considering the nationalist policy that led to the breakup of the SFRY, Montenegro's national structure, and its ability to resist the Greater Serbian ambitions of Slobodan Milosevic's regime, one can confidently conclude that Montenegro made the right decision. While other republics of the SFRY received their independence by fighting (except for Macedonia, thanks mostly to NATO and the EU), Montenegro decided to gain its independence through a democratic process familiar to all modern Western democracies. Having adopted new standards in order to hold a referendum, unprecedented at the time in the EU's experience, and acting under the influence and pressure of its High Representative for Referendums, Miroslav Laicak, the EU provided favorable conditions for the authorities and the opposition in Montenegro to adopt a law to determine what the citizens thought about independence. ${ }^{37}$ This is yet another positive example for the international community (and particularly for the EU) of successful preventive action to resolve political and security issues in the region. The way Montenegro achieved independence is the main reason that the country was recognized by the $\mathrm{UN}$ and the OSCE, as well as by many other countries and international organizations.

After the referendum in September of the same year, parliamentary elections were held at the republic level. An absolute majority of votes was received by the coalition parties - the DPS, or Democratic Party of Socialists, and the SDP, or Social-Democratic Party - that had held power during the preceding period. Although the winning coalition was led by the head of Montenegro's

\footnotetext{
36 More about the Centers and NATO Schools can be found at http://www.act.nato.int/content.asp? pageid $=330$.

37 Law on Referendums in Montenegro, Parliament of Montenegro, 1 March 2006.
} 
government at the time, Milo Đukanovic, he decided to leave his official government posts but remain as head of the DPS. ${ }^{38}$ Western commentary on this decision was generally positive, with the move considered to be smart and rational; this commentary also stressed the need for new political directions in the European and the Euro-Atlantic integration processes. ${ }^{39}$ This is an important consideration, since it is uncharacteristic for Balkan leaders to voluntarily give up power. Some time after Đukanovic's decision, Predrag Bulatović, who had been the leader of Montenegro's most powerful opposition party prior to the parliamentary elections in September, left the post of Chairman of the SNP, or Socialist People's Party.

Although the same parties that had existed previously remained, this nonetheless led to certain changes in Montenegro's political landscape. Aside from the DPS (which held thirty-four seats in the parliament) and the SNP (which held eight), other parties represented in parliament included the SNS, or Serbian People's Party (eight seats); the SPD (seven); the NS, or People's Party (two); the LP, or Liberal Party; the DSS, or Democratic Serbian Party; the DSTsG, or Democratic Union in Montenegro; and the DUA, or Democratic Union of Albanians (all of which held one seat each). There were also other parties represented in parliament that had been absent under the previous mandate, such as the PZP, or Movement for Change (eleven seats); the BS, or Party of Bosnians (two seats); and a group of parties with only one seat apiece, including the SRS, or Serbian Radical Party; the NSS, or People's Socialist Party; the DSI, or Democratic Unity Party; the KhGI, or Croatian Civil Initiative; and the AA, or Albanian Alternative. Out of eighty-one members of the parliament, seven are women. If in the past there were clear distinctions within the parliament between supporters and opponents of Montenegro's independence, the present contingent in principle focuses on the processes of European and the Euro-Atlantic integration, privatization of property in Montenegro, and issues related to the standard of living in the new nation.

To accelerate the reform process, one must begin by improving the functioning of the parliament, primarily in terms of its legislative functions, which means professionalism of parliamentarians, the forthright obligation to follow the rules of domestic order, and efficient (rational) legislative work. Greater professionalism on the part of members of parliament could ensure higher quality and more responsible work and could hinder or limit conflicts of interest. In addition, funds must be provided to engage experts in various fields who are competent to assist the deputies in developing legal and other documents. ${ }^{40}$ The Parliamentary Assembly of the Council of Europe (PSSE), which for the last ten years has monitored elections in Montenegro through its representatives, plays a significant role in parliamentary reform. The major requirements are to change election laws and adopt a new constitution, which should be the beginning of national reconciliation and the democratization of Montenegrin society. Montenegro has been presented with conditions that it must incorporate in amendments to its 1992 constitution if it is to be accepted into the Council of Europe parliament in April 2007. This includes clauses in the new constitution, adopted by resolution via a two-thirds majority in the Constituent Assembly of Montenegro, or through a statement of policy with fewer than two-thirds of the votes (which the

38 "Meeting of the DPS Presidium," Independent Daily Viesti, Podgorica (3 October 2006).

39 "Dr. Judy Bat, Expert at the European Union Institute for Security Studies (EUISS) in Paris," Independent Daily Viesti, Podgorica (5 October 2006).

40 "Analysis and recommendations for long-term development of the Montenegro Parliament, prepared by the U.S. National Democratic Institute (NDI)," Independent Daily Viesti, Podgorica (24 September 2006). 
parties will deem binding) signed by the chairman of the parliament, the government, and the leaders of the major opposition parties. ${ }^{41}$ These conditions include:

- Firmly establishing the civilian nature of the government

- Avoiding politics as a determinant in selecting judges and prosecutors

- Requiring prosecutors to represent the government in civil disputes

- Protecting human rights, at least at the level of the former Union Charter, retroactively

- Abolition of the death penalty

- Regulation of the status of armed and security forces and the intelligence community, with parliamentary oversight

- Placing a civilian in the post of commander-in-chief, as mandated by law.

Significant changes in the political system and in domestic policy from 2002 to 2006 led to improvements in Montenegro's legal system, bringing it into greater harmony with present-day European law. A total of forty-three laws were passed, of which eleven were already in the approval process and seven were in preparation. Twelve programs and strategy documents were approved, and two more were in preparation. ${ }^{42}$

However, implementation (rather than the quality of the legislation) has turned out to be a problem. In addition, in its 2007 Annual Report on the Progress of Montenegro in the Stabilization and Accession Process, Brussels expressed misgivings about insufficient activity in fighting corruption and organized crime (in the previous year's report, Brussels recommended changes in the "Law on Conflicts of Interest," but it remains unchanged). Furthermore, appointment of judges is still based on political considerations, and institutions and administrative capacities are insufficiently developed. ${ }^{43}$

With the formation of the first government in independent Montenegro in November 2006, the task of forming a new Montenegrin society that would eventually accede to membership in NATO and the EU began. ${ }^{44}$ Željko Šturanovic, the former Minister of Justice, was named Prime Minister. Judging from the mandate ${ }^{45}$ presented to the deputies in parliament and the government program for $2007,{ }^{46}$ one could conclude that the major themes to be addressed by the government of Montenegro would be in the following areas:

- Formation of an institutional and legal framework compatible with international and EU standards in all areas

41 Policy Committee, Parliamentary Assembly of the CE, Strasbourg, 23 January 2007.

42 Program and regulatory activities in the policy and foreign policy system for the period from 2002 to October 2006, Government of Montenegro, November 2006.

43 European Commission, Brussels, 8 November 2007.

44 Changes and additions to the Order on the Organization and Conduct of Governance, SLRTsG, Doc. No. 38/03.2006.

45 Željko Šturanovic, "Presentation of Mandates to Form a Government of Montenegro," the Parliament of Montenegro, 10 November 2007.

46 Work Program of the Government of Montenegro for 2007, Official Gazette of the Republic of Montenegro, Doc. No. 45/01.2007; available at www.vlada.cg.yu/biblioteka.php. 
- Achievement of rapid and sustainable economic development by increasing economic freedom, strengthening the influence of economic factors, and raising the overall level of macroeconomic stability

- Raising the population's living standard, strengthening neighborly relations, and cooperating and actively participating in regional projects and initiatives

- Joining the processes of European and Euro-Atlantic integration in the political, economic, and security arenas

- Intensifying economic reforms that will bring Montenegro's economic system closer to the international market and support sustainable and dynamic development, thereby creating an investor-friendly business climate

- Pursuing active membership in the Council of Europe and efficiently performing membership obligations, particularly those related to protecting human rights and minority rights

- Ensuring the free movement of people, goods, services, and capital via implementation of a single South Eastern European Free Trade Agreement (CEFTA 2006).

The basis for implementing these goals in the areas specified will be a new government action plan containing short- and mid-term recommendations from the updated European Partnership for an Independent Montenegro, the Accession Strategy and Main Challenges for 2006-07, and the Annual Report on Progress by Montenegro in Stabilization and Accession. $^{47}$

In the context of security reform, the government has promised to give special attention in the future to EU security and defense policy, development of political and military cooperation with NATO and countries in the region, as well as cooperation with global and regional organizations, primarily with the UN and the OSCE. The ongoing reform of the police and the development and implementation of integrated border management concepts continues, as do efforts to reform the armed forces. Full implementation of the obligations assumed by virtue of signing the Partnership for Peace Framework Agreement in Brussels on 14 November is considered essential in order to accomplish these objectives. ${ }^{48}$

The military forces of Montenegro were formed on the basis of those troops located on the territory of Montenegro at the time that the independence referendum was passed. In June, the government adopted a strategy document - the National Security Strategy of Montenegro $^{49}$ - that lays out the early stages of the process of reforming the armed forces. The Defense Strategy, Military Doctrine, the Law on Defense, and the Law on the Armed Forces are still in draft form. Based on a decision by President Filip Vujanovic on 29 July 2006, the draft has been abolished and Montenegro's armed forces is to be transformed into a professional force. The new government has also created a Ministry of Defense, which did not exist previously.

47 European Commission, Brussels, 8 November 2006. 
The reform process began by cutting the armed forces from 6000 service members in 2004 to 2500 in late 2006 . The military force now consists of the following organizational elements: ${ }^{.0}$

- General Staff of Montenegro Armed Forces

- Honor Battalion

- Military Police Company

- Special Operations Brigade

- Training and Support Brigade

- Air Force Base

- Naval Base.

All organizational structures of Montenegro's military are in the process of formation and are not yet at full operational strength. The major problems in military reform are:

- Lack of strategy documents, laws, and other regulatory acts

- A personnel structure that fails to meet current needs

- Infrastructure that fails to meet current needs

- An insufficient level of foreign language knowledge

- Obsolete equipment, armaments, and technology

- Surplus of military personnel.

It is unrealistic to expect all these problems to be solved quickly, considering that the Ministry of Defense has been established as a civilian body only recently. Following a visit to Montenegro by then-U.S. Secretary of Defense Donald Rumsfeld on 29 September 2006 and a meeting with Montenegro officials, it was announced that an agreement would be signed with the National Guard of the State of Maine. ${ }^{51}$ Multilateral military cooperation is planned via the establishment of a joint military and security system, supply of arms, regular military-civilian cooperation, and civilian cooperation to be implemented through various special courses and expert exchanges once the U.S. administration approves the agreement with Montenegro. This was followed by intensive establishment of military relationships and cooperation with the armies of neighboring countries, countries of the region, the U.S., and NATO. In addition, following a meeting between a Montenegrin military delegation (led by the Chief of the General Staff, Lieutenant-General Jovan Lakcevic) and the Greek Defense Minister Vangelis Meimarakis and the Chief of the Greek General Staff Panagiotis Kinofotis on 6 February 2007, it was agreed that Greece would serve as the "contact point" for Montenegro's cooperation with NATO. The national defense structure of Greece will assist Montenegro in dealing with personnel issues and modernizing its military. Under this agreement, an exchange of experts from the two

50 More information is available at www.vcg.cg.yu.

51 Independent Daily Viesti, Podgorica (29 September 2006). 
countries' General Staffs will soon be arranged to finalize the details of future cooperation. $^{52}$

When NATO intervened militarily in FRY in 1999, Montenegro officially supported this action and openly opposed the regime in Belgrade. This led to strained relations between the Yugoslav and the Montenegro police, which at the time numbered more than 20,000. After these events, only the police were able to guarantee Montenegro's security until it gained independence in 2006. While other countries of the former Yugoslavia obtained independence in a different manner, placing primary emphasis on reform in the military and defense structures, in Montenegro the emphasis was on reforming the police. Accordingly, the other Yugoslavian republics had military veterans and distinguished warriors, while Montenegro had distinguished police officers, which complicated the reform process.

Reform began in April 2002 with the adoption of "Principles of the Strategy to Reform the Ministry of Internal Affairs of the Republic of Montenegro." The next step was to sign an agreement on cooperation between the Montenegro Ministry of Internal Affairs and the Danish Institute for Human Rights (DIHR) on 24 September 2003, aimed at developing and implementing an MIA reform plan that would be financed by the Danish Ministry of Foreign Affairs. A cooperation agreement with the OSCE was signed on 1 March 2004. This represented the beginning of coordinating international assistance to support overall reform of the MIA. Under this agreement, a Strategic Planning Unit was formed to cooperate with the OSCE and the DIHR, and together they developed the MIA Development Vision Document. ${ }^{53}$ Two more plans were developed in cooperation with the OSCE. One of them, called "The Police in Local Society," was aimed at putting the police in service to the people; this plan has not yet been implemented, although the OSCE has completed comprehensive training of all members of the Montenegro Police. ${ }^{54}$ The second, called "Reform of Montenegro Police Training," was the basis for the establishment in September 2006 of the Police Academy in Danilovgrad. ${ }^{55}$ Aside from these activities, the Montenegro Police gained significant security competency in guarding the borders of Montenegro from the armed forces of the federation during late December 2003.

Unfortunately, not all these activities had made significant progress in police reform prior to passing of the new Law on the Police ${ }^{56}$ and the Law on National Security, ${ }^{57}$ under which the police and the National Security Agency were moved out of the organizational structure of the Ministry of Internal Affairs. The establishment of the Committee on Security and Defense ${ }^{58}$ and the Council for Civilian Control of the Police ${ }^{59}$ provided parlia-

52 Independent Daily Viesti (7 February 2007).

53 Vision Document, Book I, II, III (Podgorica: Republic of Montenegro, Ministry of Internal Affairs, May 2005).

54 Decision to begin implementation of the plan: "Police in Local Society," Government of Montenegro, 2004.

55 Reform of the Montenegro Police, Resolution No. 02-60/1, Government of Montenegro, 2005.

56 Law on the Police, Official Gazette of Montenegro, No. 28/1, Podgorica, 2005.

57 Law on the National Security Agency, Official Gazette of Montenegro, No. 28/2, Podgorica, 2005.

58 Decision to Form Departments of the Parliament of Montenegro on Security and Defense, Official Gazette of Montenegro, No. 36/3, Podgorica, 2005. 
mentary and civilian control of these important security entities. The present Director of the Police, Veselin Veljović, is the first chief of the police organization to have been required to undergo scrutiny by the Security Committee before assuming his post. He reported on his work program and responded to parliamentarians' questions. Significant changes were made to the personnel structure, which resulted in police professionals being put in crucial posts. In September 2006, the Montenegro police created a special anti-terrorism unit to deal with terrorism within Montenegro. On September 19, the Montenegro Police Administration was accepted as a full-fledged member of INTERPOL at the international police association's General Meeting in Rio de Janeiro. The MPA then established contacts among the international police community.

But despite this strong trend to reform policy in Montenegro, the nation is still faced with many problems that it is not yet prepared to address, such as:

- Lack of a strategy to develop Montenegro's police

- Corruption and organized crime

- Personnel redundancy

- Lack of professionalism among the police

- An outmoded model for police work

- Lack of a modern information infrastructure

- Lack of qualified specialists with foreign language abilities.

New procedures for the organization and systematization of job positions within the police administration were adopted early this year, ${ }^{60}$ representing yet another effort to complete the process of improving resource utilization and developing professional personnel within the police structure. Also, the Ministry of Internal Affairs has adopted a "National Strategy for Emergency Situations" on the basis of which Montenegro could find solutions to the challenges of crisis management. ${ }^{61}$

A number of non-governmental organizations have been included in the Euro-Atlantic integration process in addition to the armed forces and the police. The Euro-Atlantic Club in Montenegro was established in November 2006, and by December was already accepted into the Atlantic Treaty Association (ATA). In January, the Youth Atlantic Treaty Association (YATA) was formed. ${ }^{62}$ Also very active is the Center for Civilian Education, which together with the Center for the Development of Non-Governmental Organizations and the European Movement in Montenegro has thus far organized four-month sessions of the School of European Integration. ${ }^{63}$ In addition, the Center for Democracy and Human Rights (CEDEM) plays a significant role. Unfortunately, it is the only organization in

59 Article 93, Law on the Police, 2005.

60 Procedures for Organization and Systematization of Job Positions in the Police Administration of Montenegro, January 2007; additional information available at www.upravapolicije.vlada.cg.yu.

61 National Strategy for Emergency Situations, Government of the Republic of Montenegro, Podgorica, 2006. Additional information available at www.atacg.org/en/index.php.

63 Additional information available at www.cgo.cg.yu. 
Montenegro conducting polls of public opinion on issues related to European and EuroAtlantic integration. ${ }^{64}$

One of the greatest challenges in the early stages of Montenegro's engagement in the Partnership for Peace is the lack of scientific personnel in certain key fields. For example, there is not a single university division or department studying security issues. There is also an absence of research and scholarly publications in the field of security or security integration - research that is needed for the process to fully achieve the objectives of Montenegro's membership in NATO and the EU.

\section{Capabilities, Needs, and Experiences from the Immediate Environment, and Montenegro's Priorities in the Partnership for Peace Program}

To know with confidence what a society, organization, or institution needs at a given point in time, one must have accurate indicators from appropriate areas, as well as people who are able to utilize those indicators. A well-developed strategic planning mechanism for such purposes exists at the institutional level in NATO member countries. On the other hand, there is also a well-developed mechanism for long-term observation and analysis of planning activities that have been implemented, which has the reciprocal function of improving and supporting the continuity of strategic planning. In theory, all of this is an ongoing process of observing the relationship between capability and needs and finding appropriate solutions indicated in especially important strategy documents.

Capabilities can in principle be determined with confidence, as they are limited by certain factors or indicators of actual conditions. On the other hand, needs are naturally endless, but the ability to fulfill them is limited by available resources. Finding the optimal balance of needs and resources is a step toward attaining the ultimate goal. In analyzing the relationship between resources and needs, a key consideration is the national budget available to finance certain needs. It determines the unavoidable realities of limited resources throughout the fiscal year. Essentially the budget is the basic measure of how to meet needs during the year. To maintain continuity in the security sector throughout a given period, a strategic review of documents is often conducted in order to look at the overall situation in the defense sector. The elements of this review include:

- Security environment

- Foreign policy and its influence on defense policy

- National defense and security interests

- Security threats and risks assessment

- Defense policy

- Defense policy goals and objectives

- Defense system status and military capabilities

- Defense system organization

- Status of human resources, material interests, and finances

64 Additional information available at www.cedem.cg.yu. 
- Mission, vision, and goals of the military

- Functions of the military

- Organization of the military

- Resources required for the military to perform its functions

- Required defense system capabilities and development priorities

- Major prerequisites for defense planning

- Development of the MOD organization in the near term

- Development of the military organization in the near term

- Development of logistics

- Development of an intelligence-security system

- Development of human resources and ability to support planned forces

- Development of a telecommunication-information system

- Development of a scientific research system

- Defense system cost projections

- Priorities of development, modernization, supply, armaments, and military equipment

- Strategy for the implementation of organizational changes.

In addition to the strategy review, there is another document of great importance to studying possibilities for satisfying defense needs: a long-range plan for building the armed forces. This plan begins with drafting a defense system development plan and studying the required budget resources. Unfortunately, Montenegro does not yet have such strategy documents, and the budget available for developing the defense system is modest, at 41 million Euros. ${ }^{65}$ And while this is a relatively small defense budget, if 2 percent of the nation's GDP (2.28 billion Euros in 2007) must be allocated in order for Montenegro to achieve interoperability with NATO forces, this 41 million Euros represents a significant proportion (over 7 percent) of Montenegro's national budget that is being devoted to rapid and effective reform of the defense sector. Let's compare, for instance, Croatia's 1.7 percent allocation for the needs of its armed forces in 2007; this comes to approximately $680,000,000$ Euros, which is spread across armed forces made up of 20,000 service members. This represents a larger amount than Montenegro allocating 2 percent for its 2,500 servicemembers. The difference is that Croatia's GDP is significantly larger. Considering that the Montenegro military does not have obligations to its troops and veterans, as is the case with the armies of the other former Yugoslav republics, it can take advantage of the benefits offered by the PfP to move more quickly and effectively toward reform based on the actual resources at its disposal.

65 Budget of the Republic of Montenegro, Government of Montenegro, 2007, 104. 
The police budget for Montenegro exceeds the defense budget, and stood at EUR 50 million in 2007. ${ }^{66}$ To achieve EU standards, which call for three to four police officers per one thousand inhabitants, the Montenegro Police will have to quickly reduce its present numbers by $50-60$ percent. This will be difficult, considering the important role played by the police in the process of attaining independence.

When one analyzes key parameters of Montenegro's security resources and needs-including political and demographic considerations, geographic factors, the regional security environment, and security threats specific to Montenegro - there is a genuine necessity for the government of Montenegro to consider the possibility of developing a plan to establish a gendarmerie, or military police function. ${ }^{67}$

A military police organization, or gendarmerie, could be formed from existing military organizations - such as the Special Operations Brigade and military policy company, police units of the Police Administration, and special anti-terrorism units and separate police units - which have similar structure and operational approaches. This organization could become part of these forces for purposes of integration into the EU. ${ }^{68}$ Along with appropriate support from the air force and the navy, the military training and support brigade, the Police Academy in Danilovgrad, and the Center for Underwater Mine Disassembly in Bijela, they could quite reliably deal with security threats and challenges on land or sea, and in a narrow or broad security zone. In the continuing process of developing the gendarmerie, they could even participate with other Partners in joint operations led by NATO or the $\mathrm{EU}$, which are similar in terms of their nature and the need to engage combined militarypolice forces. ${ }^{69}$

\section{Lessons Learned: The Example of Slovenia}

Lessons learned, particularly those learned from countries that have undergone a similar integration experience, will play an irreplaceable role in the process of making decisions to develop strategic documents, laws, and PfP instruments. Slovenia, which became an EU and NATO member in 2004, and Croatia, which is well on the way to EU and NATO membership, have experience that is invaluable for Montenegro.

Immediately after becoming independent in 1991, the National Congress (Parliament) of the Republic of Slovenia adopted a new democratic constitution. ${ }^{70}$ Slovenia has been a PfP member from the very start. In its integration experience, priority was given to quickly drafting strategy documents and laws. In 1994, the first separate program under the PfP was established. Participation in NATO exercises began in 1995, and in 1997 Slovenia

66 "Address by Director of the Police of Montenegro, Veselin Veljović," Independent Daily Viesti, Podgorica (21 December 2006).

67 Interview with Professor Anton Grizold, Dean of the Department of Political Science in Ljubljana (Slovenian Defense Minister when Slovenia joined the NATO), Sipan-Dubrovnik, Croatia, 13 July 2006; interview with Ambassador Dr. Prezymuslav Grudzinski, Professor at the George C. Marshall Center, Garmisch-Partenkirchen, Germany, 4 February 2007.

69 Anton Grizold and Lidiya Chehulic, International Security and NATO in a New World Order (Zagreb: Faculty of Political Science, 2006), 58.

70 Constitution of the Republic of Slovenia, Ljubljana, U1 RS, No. 33/1991. 
started participating in international peace operations. In 1996, in cooperation with NATO, the PARP process began - the single most vital instrument for executing the required reforms in the Slovenian armed forces and security structures. There is little room in such a process for improvisation or acts that are less than transparent to the public and to all NATO members. PARP was also open to the exchange of various ideas, referring to the structure and potential of military forces that Slovenia would need for future NATO membership. After the NATO Summit in Washington in 1999, Slovenia adopted a MAP for accession and developed four annual national programs. In developing its defense system using the MAP in cooperation with NATO experts, the importance of becoming a NATO member became clear.

In the same manner, the MAP represented a practical tool to identify weaknesses in the country's defense structure and establish the required links within the project to restructure the Slovenian armed forces. In the process of studying the program for future adaptation to NATO structures, one of the first steps was a general adoption of the principles of socialization and diversification among the Allies and their armed forces restructuring and modernization programs. The National Assembly of Slovenia adopted a number of important documents in that area, including a general long-term program for developing and supplying the Slovenian military for the term 2002-07, and size and structure projections for the military for both the short term (until 2004) and medium term (until 2010).

Significant progress was made in defense planning by using this experience. The Slovenian government ensured stability in the reform process by adopting a long-term budget. Accordingly, a long-term strategy (extending to 2015) for modernizing the military was established, with the goal of creating conditions consistent with the demands of the new security environment. Establishing a consistent and effective personnel policy proved a most difficult challenge. For that reason, the Law on Defense ${ }^{71}$ (a Law on the Professional Armed Forces was also adopted) called for reform of public administration. In accordance with this, the Slovenian government decided to abolish conscription starting in June 2004, and continued a requirement to serve in the reserves through $2010 .^{72}$ The armed forces command expressed the expectation that it would achieve full professional strength by 2008. At the same time, a volunteer reserve was planned until 2012.

In terms of defense reform, this process was tied to certain conditions: political consensus and support, finances, and changes to the education system. After NATO's official invitation to initiate accession negotiations in 2002, Slovenia conducted a public referendum on joining NATO and the EU, which was supported by the citizens. Increased defense spending was one of the government's newest decisions. In June of 2002, the government approved a defense spending plan for 2003-08. Defense spending was to gradually increase through the ensuing years until it reached 2 percent of the GDP. A two-year budget was approved, ${ }^{73}$ and the Law on Basic Development Programs was extended to 2007, which represented a real and stable start to managing the country's defense resources for that period. For 2002-08 the plan calls for gradually increasing the level of de-

71 Law on Additions and Changes to the Law on Defense, Ljubljana, Ul RS No. 40/2004.

72 Anton Grizold, "Slovenia in a Changed Security Environment," Ljubljana, 2006.

73 Law on calculations performing [unk], Republic of Slovenia in 2003 and 2004, Ljubljana (ZIPRS0304), Ul Republic of Slovenia, No. 121/2003. 
fense spending relative to GDP from 1.6 percent (USD 304 million) in 2003 to 2 percent (USD 616 million) in 2008. Distribution of these funds was governed by the Constitution of Slovenia. Based on Article 92 of the constitution, the National Congress makes decisions on the utilization of the armed forces and the declaration of national emergencies, while the president of the republic is the commander-in-chief of the armed forces, based on Article 102 of the constitution. The process of reforming the rest of the security sector proceeded in parallel to this reform.

\section{Lessons Learned: The Example of Croatia}

Croatia became a Partnership for Peace member in 2000, but was unprepared to begin the process. At the time Croatia did not have a single strategy document, and its personnel potential was unprepared to take on the transformation challenges associated with entry into the PfP. During the first NATO accession cycle, transformation must be accomplished with respect to all segments of society, particularly in the security sector. Changing opinions on the process of making the adjustments required for PfP membership was initially an intellectual exercise; it then became an institutional and political issue, and only at the end did it become a military question. ${ }^{74}$ Croatia's formal participation in PARP began in October 2000, when the Croatian government responded to NATO's questionnaire on PfP interoperability. Partnership goals, intended to enhance interoperability between Croatia and NATO, occupied a special place in the PARP. Croatia is now working on implementing forty-nine partnership goals that largely govern the process of making changes in the Croatian armed forces, as well as in the governmental structure, and they cover many areas of cooperation required for accession to NATO membership. In February 2001, NATO approved the first Croatian Individual Partnership Program for 2001. This document contained a list of PfP activities in which Croatia wished to participate during its first planning cycle. This involved opening a mission at NATO Headquarters in Brussels and a Croatian office at the PfP, which served to promote greater interaction and intensity of contact between Croatia and NATO.

By May 2001, Croatia was invited to join the Membership Action Plan (MAP). Croatia then adopted a number of strategy documents and laws aimed at reforming its security sector. After assuming the obligations of the MAP, Croatia developed its first Annual Membership Program in 2002-03, which stressed its "strong commitment to joining NATO." Based on this fact, fulfilling the criteria needed to become a member was now not just an obligation of the defense and foreign ministers, but of the entire government. ${ }^{75}$ During 2002 Croatia proposed several programs under the Partnership Work Plan, which offers over two thousand activities in thirty-three areas, where each Partner can choose to make proposals. That same year a joint exercise called "Taming the Dragon-Dalmatia 2002" was conducted in conjunction with the Euro-Atlantic Disaster Response Management Center.

Thus far, Croatia has completed three MAP cycles and is currently in its fourth. During 2003 Croatia joined the U.S.-Adriatic Charter, established under an initiative at the NATO Summit in Prague in 2002. The U.S.-Adriatic Charter, based on the principles of the Baltic

\footnotetext{
74 Vukadinovic, et al., NATO in International Relations, 153.

75 Ibid., 160.
} 
Charter (Vilnius Assembly), ${ }^{76}$ envisions principles and cooperation commitments for Albania, Croatia, and Macedonia on their course to full membership in NATO. The document requires the strengthening of democracy, protecting minority rights, fighting terrorism, countering foreign crime and weapons of mass destruction, and furthering security sector reform. In 2006 Croatia adopted the Strategic Defense Review and a Long-range Development Plan for the period from 2006 to 2015.

Based on this experience, one can identify certain steps that should be priorities for Montenegro as it goes about making decisions related to its first year of participation in the Partnership for Peace. At the national level, the following steps are crucial:

- Adoption of a new Montenegrin constitution based on EU principles and standards, to meet methods and standards for managing the defense and security sector

- Creating institutions for democratization of the defense and security sector and ensuring civilian control over them ${ }^{77}$

- Developing, refining, and coordinating these institutions with constitutional clauses, and adopting strategy documents, laws, and other statutory acts required to successfully implement the commitments Montenegro assumed prior to joining the $\mathrm{PfP}^{78}$

- Developing a presentation document entitled "Montenegro and the Partnership for Peace" that would outline the priorities and goals of Montenegro under the Program and would serve as the basis for subsequent, more detailed plans ${ }^{79}$

- Creation of a diplomatic mission at NATO HQ in Brussels and an office in the Partnership Coordination Cell, staffed by appropriate civilian and military personnel. This is necessary to promote unhindered communication and timely coordination in developing required documents and instruments for Partnership reorganization and to tailor the government administration to the needs of the PfP

- Professional development of personnel in government bodies, with special emphasis on security issues $^{80}$

- Intensive language study in all government institutions directly related to implementing the measures required by the PfP.

At the level of the Ministry of Defense, the following steps must be taken:

76 Ibid., 173.

77 Interview with Dr. Fritz Rademacher, Professor at the George C. Marshall Center, GarmischPartenkirchen, Germany, 26 January 2007.

78 Ljubisa Perovic, Deputy Minister of Defense for Defense Policy, said that "the Law on Defense and the Armed Forces and the strategy documents Defense Strategy and Military Doctrine are in the final intensive phases, but there is a strong opinion that there is no need to hurry, considering the importance of such documents, and that they must ultimately pursue the process of preparing and adopting a very important government act." Independent Daily Viesti, Podgorica (8 February 2007).

79 Interview with Dr. John Kriendler, Professor at the George C. Marshall Center, GarmischPartenkirchen, Germany, 25 January 2007.

80 "Experience of Slovenia, Dr. Special Advisor to the Government of Slovenia on EU Relations," Independent Daily Viesti, Podgorica (6 December 2006). 
- Creation of a PfP Planning, Coordination, and Analysis Group. This group would include representatives of other government institutions that are vital to implementing the goals of the Partnership. Its role would be most visible in coordinating and supporting intra-institutional cooperation, both with NATO and within Montenegro, and especially within the defense and foreign ministries ${ }^{81}$

- Training defense ministry personnel at NATO schools and training centers. Such training must be consistent with the priorities identified in the presentation document. During the initial period, training should be geared to defense reform and everything associated with that process (establishment of democratic institutions, democratic control, development of documents and instruments under the PfP, and so forth) ${ }^{82}$

- Implementation of existing strategy documents and laws, as well as drafting of new ones

- Development of an Individual Partnership Plan based on cooperation priorities, in order to begin the process of achieving interoperability through activities in the area of operations and material and administrative standardization ${ }^{83}$

- Conducting the necessary preparatory work to join the NATO PARP in order to establish a basis to identify and assess forces and capabilities that may be available for multinational training and joint operations with NATO forces

- Initiating a public information campaign aimed at educating the public about the importance of the principle of transparency and public participation in the process of NATO accession. ${ }^{84}$

\section{Conclusion}

Not all countries that have passed through NATO's Partnership for Peace Program on their way to full NATO membership have been confronted with identical security challenges and threats, both in the Euro-Atlantic zone and beyond. Thus, all NATO members have been accepted into NATO in different ways. For example, the Czech Republic, Hungary, and Poland became full members within less than a decade after the end of the Cold War, in a significantly different security environment than the one which currently exists. Circumstances have changed with time, and at its summits NATO has consistently undertaken initiatives and made suggestions on how to respond to security challenges.

The main characteristics of the current security environment, with directives and priorities for the next ten to fifteen years, were articulated at the NATO Summit in Riga on 28-29 November 2006. These are particularly pertinent for Bosnia and Herzegovina, Montenegro, and Serbia, for whom they represent the basis for discussing policy goals and practical actions for their processes of NATO accession. Global terrorism, with the capa-

81 Interview on the experience of Croatia with Dr. Dragan Lozancic, Professor at the George C. Marshall Center, Garmisch-Partenkirchen, Germany, 9 February 2007.

84 Address by Defense Minister Boro Vucinic at the International Conference "NATO and Public Relations," as reported in the Independent Daily Viesti, Podgorica (2 December 2006). 
bility to inflict increasingly lethal consequences, and the proliferation of weapons of mass destruction are likely to be the major threats to the Alliance in the next ten to fifteen years. The major challenges associated with this new threat scenario include:

- Instability resulting from the collapse of existing state governments

- Regional crises and conflict

- Increased availability of sophisticated weapons systems

- Misuse of technology and violations in delivering vital resources

- Obstacles in providing vital resources.

The Alliance will continue to pursue a policy of broad access to security, as reflected in the 1999 strategic concept, with primary emphasis on security, mutual consultation, armaments and defense, crisis management, and partnership. In pursuit of these goals, NATO has a number of requirements:

1. The Alliance will require energy and adaptability to respond to complex and unpredictable challenges, while ensuring effective interaction in sharing information and intelligence

2. The Alliance must maintain the ability to carry out large high-intensity operations and a variety of low-intensity operations simultaneously

3. Each operation will seek a command and control structure capable of planning and executing strategic and operational tasks

4. For the purpose of executing operations, the Alliance requires an additional number of ground forces and corresponding sea and air components. This is supported by policy decisions on the requirement for 40 percent deployable ground forces and 8 percent in operations

5.NATO and the EU must continue to develop procedures for ensuring coherent and transparent relations and interaction in developing capabilities common to both organizations

6. Increasing investments in key capabilities will require members to change priorities and efficiently use resources, to include combining forces and other forms of cooperation

7. As the security environment changes over the next ten to fifteen years, so will the need to counter conventional and asymmetric risks and threats, which will be the basis for achieving the following capabilities:

o Execute and maintain multinational and joint expeditionary operations in remote locations, with minimal (or no) support from the country where the operations are being conducted

o Head off, thwart, and defend against terrorist attacks

o Protect information assets

o Conduct operations involving the threat of possible use of WMD and the ability to use NATO forces to deal with a missile attack

o Conduct operations in challenging geographic settings and climates 
o Demonstrate capability and flexibility in conducting operations in conditions where it is necessary to coordinate with local authorities, institutions, and governments

o Provide military support to stability operations and reconstruction efforts through all phases of a crisis, including the security phase; this includes security sector reform, demobilization, disarmament and reintegration, and military support for humanitarian operations

o Capability of practical interoperability and standardization with allies, as well as flexibility in cooperation with partners

8. Implementing these capabilities will require being open to new technologies, concepts, and doctrines. This includes improving the ability to assess the situation and timing for planning operations and decision making.

The main priorities for NATO in meeting these requirements include the development of common expeditionary forces and the capability of supporting them; the preparation of rapidly deployable forces; the ability to deal with asymmetric threats, such as those often posed by terrorist actors; ensuring a position of information superiority; continuing to build the ability to more effectively utilize all of the Alliance's instruments in a crisis; and effectively coordinating with all actors, both NATO members and Partner nations. ${ }^{85}$ How Montenegro ultimately uses the advantages accruing from participation in the Partnership for Peace, which priorities it chooses, and what contribution it makes to the Alliance and to the Partnership will depend primarily on its own decisions.

${ }^{85}$ NATO Summit in Riga, Latvia, 28-29 November 2006, NATO publications, www.nato.int/docu/ pub-form.htm. 


\section{THE QUARTERLY JOURNAL}

\section{Bibliography}

Carter, Ashton, William Perry, and John Streinbruner. A New Concept of Cooperative Security. Washington, D.C.: The Brookings Institution Press, 1993.

Cohen, Richard, and Michael Mihalka. Cooperative Security: New Perspectives on the International Order. Garmisch-Partenkirchen: George C. Marshall, European Center for Security Studies, 2001.

Dewit, David. "Common, Comprehensive and Cooperative Security." The Pacific Review7, no. 1 (1994).

Grizold, Anton, and Lidiya Chehulic. International Security and NATO in a New World Order . Zagreb: Faculty of Political Science, 2006.

NATO Glossary of Terms and Definitions In NATO Standarization Agreement AAP-6., 2008.

Simić, Dragan. "The Science of Security: Contemporary Approach to Security." Belgrade: Official Gazette of the FRY and the Faculty of Political Science (2002): 65-82.

Vukadinovic, Radovan, Lidiya Cehulic, and Drago Lovric. NATO in International Relations. Zagreb: Faculty of Political Science, 2006.

Vukadinovic, Radovan. Post-Cold War Trends in International Relations. Zagreb: Faculty of Political Science, 2000. 